\title{
Modernistic Characteristics in the Poetry of Emily Dickinson
}

\author{
Dongxiao Peng \\ English department of foreign language school \\ Zhengzhou, Henan, China
}

\begin{abstract}
As a great precursor of modernistic poetry, Emily Dickinson influences the latecomers a lot from the content to the form in perspective of poem creation. This paper mainly discusses the modernistic features of her poetry. From titles to endings of her poetry, modernistic tendencies can be discovered. The images and concealment, special use of punctuations are impressive in manifestation of modernistic characteristics.
\end{abstract}

\section{Keywords—modernism; form; Emily Dickinson}

\section{INTRODUCTION}

Emily Dickinson is regarded as the grandmother of American poetry. Dickinson created 1775 poems, but only seven were published during her lifetime. Dickinson's poems concern love, death, nature, immortality and beauty. Much research has been done on her subjects. If the form of the poem is the carrier of the poet's mind, we may conclude some of Dickinson's thoughts from her forms. Besides being a representative of a transcendental poet, Dickinson can be regarded as the precursor of modernism (Lowell). Much research has been done on the theme of her poems; the modernistic features in form and content of her poems are freshly explored in detail.

Modernism is a general term applied to the wide range of experimental and pioneering trends in literature of the early 20th century. "Modernist literature is characterized chiefly by a rejection of 19th-century traditions and of the conventions of realism or traditional meter. Modernist writers tended to see themselves as an avant-garde disengaged from bourgeois values and disturbed their readers by adopting complex and difficult new forms and styles"( Baldick).

The Modernist had a fervent desire to break with the past, rejecting literary traditions that seemed outmoded and diction that seemed too genteel to suit an ear of technological breakthroughs and global violence. Artists from all over the world to join in the ferment of new ideas and movements: Cubism, Constructivism, Futurism, and Imagism were among the most influential banners under which the new artists grouped themselves. The modernists broke with the tradition from the content to the form .Some of the formal features can be traced back from Emily's poems. The paper will discuss the modernistic formal characteristics of Emily Dickinson's poetry, which can manifest the formal characteristics of Modernism.

\section{THE ABSENCE OF THE TITLES}

The title is conventionally regarded as the essence and subject of a work. However, we find no title in the poems of Dickinson. On the one hand, it means that she did not want her works to be published; on the other hand, according to her, a poem should be without ending, and the title will interrupt the continuity. All of her poems can be unified into one; they are continuous. However, the readers find her poems as an entity; they are separated from each other as their various themes. So, her poems can be regarded as a discontinuous narrative, her aims by not titling closely resemble those of later modernist poets. And as Robert Pinsky has summed up: "Modern poetry often expressed or implied certain persistent ambitions, ambitions which have to do with giving the poem some of the status of an object or phenomenon" [4].

One way to show the effects of not titling can be felt in the well-known "A Narrow Fellow" by not naming the Grass" the speaker never refers to the "Fellow" as a snake, but as "he" " him" " fellow" and one of " nature's people." These references, because they are unspecific, create a feeling of familiarity or apprehensiveness, or both. The speaker also identifies the speaker "Fellow" metaphorically and metonymically through an accumulation of its details about its appearance and environment: "the grass divides as with a Comb" and "he likes a Boggy Acre." Although the word "snake" never appears in the poem, we readers can be identified with the fellows through the clue, such as "spotted shaft" and a "Whip Lash/Upbraiding in the Sun." The word or the concept "snake" came into our mind during our first reading of the poem, and will be there invisible in the further reading. So, although this poem does not have a title, it is no less impressive than a poem with a title, and even much more impressionable because of the defamilarization for the absence of the title to arouse the readers' curiosity and imagination.

\section{MODERNISM IN CONTENT}

\section{A. The Use of Image}

Modernist poetry in English is generally considered to have emerged in the early years of the 20th century with the appearance of the imagist poets. Imagism laid emphasis on the economy of expression and the use of a dominant image. In Dickinson's letter to her friend T. W. Higginson in 1870, she had this criterion for judging a poem: "if I read a book and it 
makes my whole body so cold that no fire can ever warm me, I know this is poetry. If I feel physically as if the top of my head were taken off, I know this is poetry. These are the only way. I know it, is there any other way? "She emphasized intuition and strong feelings stimulated by the images created by words in the poetry. Imagination without image is useless, which is in accordance to the belief of Imagism, which emphasizes the importance of images.

Emily Dickinson is proficient in the use of images to express abstract inward and philosophy of her. In her a Bird Came Down the Walk (328), I offered him a crumb/ And he unrolled his feathers/ And rowed him softer home-/ Than Oars divide the seam-/ Or Butterflies, off Banks of Noon/ Leap, plashless as they swim. The image of the soft and elegant flight of a bird is shown. It also reminds the author of the countryside, the short fences. And in her "the Cricket Sang" (1104), it depicts the scenery of the dusk. Only the beginning, a variety of images came to our mind, "the cricket sang", "the low grass loaded with the dew" and "the workman." We are deeply impressed by the quiet atmosphere in the dusk. The above two poems are both about nature, even there are images in Dickinson's poems about death. For instance: I died for Beauty - but was scarce."(449) Readers can hear two people talking with each other, but they are dead and lying in their coffins. One died for beauty and the other died for truth. From this poem, readers even are not frightened with death, because they can still talk to each other after death. There is a little humor in it. So, there is no exaggeration to regard Emily Dickinson as the pioneer of the imagism.

In the well-known poem "There Is a Certain Slant of Light ": There is a certain Slant of light/Winter afternoon/That oppresses, like the Heft/ Of Cathedral Tunes-(130) "Heft" means weight, with a further note of heaving, strain, and oppression. The Cathedral tunes oppress because of the sullen weight of faith that they ask the listener to receive and lift. Light and sound are given weight, a synthesis that presents a vivid picture of the light's oppressive effects upon the speaker and emphasizes her inner feelings of pain and gloominess.

\section{B. Concealment}

The formal characteristics of modernism embody the word 'concealment' well. 'Conceal' and 'chaos' structure is almost the common characteristic in modernistic work. And Dickinson's unique style justifies the concealment. Besides Dickinson's peculiar images, there are also uses of irregular grammatical forms and special rhyme and meter, as well as unconventional use of metaphor contributing to the concealment.

1) Original Use of Dashes: Dickinson's dashes are probably the most recognizable literary device she uses. These dashes endow Dickinson's poems with another kind of vitality. They perform varied functions in different poems. Firstly, the dashes are used to slow and focus the reader's attention. Secondly, the dashes are also used to produce a visual effect; thirdly, the dashes also represent musical beats and can be taken to imitate rapping to achieve a kind of musical effect. And fourthly, but not the least one, sometimes, the dashes reveal the speaker's emotions and psychological experience. The dash makes the readers stop in reading, whereby the thinking and images of the poem is not interrupted, the thinking of the author moves from one point to another naturally and makes the whole thought continue as a line. Dickinson's use of dashes underlies the continuity of mind beyond the description. The above are only small portion of the ideas about Dickinson's dashes; there are still many others worth considering.

2) Arbitrary Use of the Capitalized letters: Dickinson arbitrarily uses capitalized letters usually for emphasis. And sometimes, they can stand for images, which can help us understand the general idea. For instance: in the poem "I'm Nobody! Who are you?" (298) "Nobody" "Somebody" "Frog" "Bog", the initial letter of the four words are capitalized. In fact, they are the emphasized ones. Somebody is like the dull frog, and those who support them are just in the bog, so Dickinson would rather be a Nobody rather than somebody. The subject of the poem can easily be generally grasped merely from these four words.

3) Rhetorical Devices: There are many rhetorical devices in her poems, such as paradox, pun, and the most frequently used one is the metaphor. In "I heard a Fly buzz-when I died" (465), fly is not the conventional symbol for the disgusting, dirty, noisy thing but a metaphor for despair. It is known that an unconventional use of metaphor is a formal characteristic of Modernism. Besides, she always omitted the "s" Which should be used in the third-person singular form in the verb's present form. For instance: "the patent lost/ None buy it any more - say, Foot/ decide the point - / the lady cross, or not?" (340). Dickinson did this to suggest the continuality of the actions. Above all, irregular grammatical forms indeed help the readers' understanding the meaning and themes of her poetry. They are usually regarded as the tools to communicate with the past Dickinson. They are irregular on the surface but purposeful indeed. Such originality of her poems justifies the requirement of newness of forms in Modernistic works.

4) Special rhythm: Emily Dickinson's poems are usually very short and concentrated. Many have no more than 8 or 12 lines. She did little experimenting with rhythms, almost always using the conventional meters found in her father's hymnbook, although Dickinson often combined several in one poem. However, Dickinson showed extraordinary originality in her use of assonance or half- rhymes and sound effect. The structure of Emily Dickinson's poetry was influenced a lot by hymns. Almost all the time, Dickinson took her poetic rhymes chiefly from the standard hymns of her day in which her common meter permeates. In Emily Dickinson's poetry, this simple form became a surprisingly powerful tool to describe new, strange and complicated thoughts. However, Dickinson was not a poet that always obeys the rules. Instead, she made new kinds of technical innovations. To avoid using an imprecise word for the sake of rhyme, she simply made a 
revolutionary innovation: expanding the kinds of echoes that qualify as rhyme.

Besides exact rhyme (room/'broom) and slant rhyme (room/brim), she added assonant rhyme (room/bruise), thus multiplying the supply of rhyme words many times over. Sometimes, she resorted to rhyme by vague resemblance (freeze/privilege) or skipped the rhyme entirely. The partial or slant rhymes are especially effective in helping her to compose swiftly and to focus on selection of words and metaphors, giving free rein to her imagination.

\section{NON CLOSED END}

Ending is the summarization of the above to make the whole work complete both in form and meaning. There is another kind of ending; the ending is not the stop of the work but the continuity of the meaning, which is "infinite in length but infinite in meaning" (Zhou). And such kind of ending is the non closed end. "The Non closed end always exemplified in the deviation of the styles to get the prominence and make it defamiliarized, and finally get the effect of foregrounding" (Zhou). In other words, the prominence of the style is the main symbol of the non closed end. And most of Dickinson's poems are of such a kind. Some of her poems ending with a special pattern of sentences, such as firstly with the question sentence in her "Title divine - is mine" with "In a Day_/Tri Victory" My Husband"-women say_-/Stroking the Melody-Is thisthe way?"(1072); secondly, the "if" conditional sentence, in her "As Watchers hang upon the East" with "Heaven to us, if true." as the open ending; thirdly, the negative sentence, such as "This timid life of Evidence/Keeps pleading- "I don't know."(696); and fourthly, the exclamation sentence, for instance: But why compare? / I'm" Wife"! Stop there! (199) and in some of her poems, the whole picture of the poem is vague but at the ending by the use of an abstract word. For instance: It is a lonesome Glee-/Yet sanctified the Mind/With fair association-/Afar upon the Wind/A Bird to overhear/Delight without a Cause-/Arrestless as invisible/A matter of the Skies. (774) describes the hummings from the distance, but the last few words make it hard for us to define the limits of happiness, and impress the readers deeply. There are also some different versions of endings in a poem, so the readers themselves should judge which one is much better. However, in the author's own opinion each one has its merits. So Emily Dickinson may have realized the indefiniteness of the result, just like some of the postmodernism literary works, which are ended by different results in one work to provide the readers more spaces to imagine and to prove the uncertainness of the world. Each ending seems reasonable and feasible.

\section{CONCLUSION}

As one of the greatest poets, Emily Dickinson is also the most original one. Among all the great writers of the nineteenth century, she had the least influence on her age. Emily Dickinson did not write for publication, and perhaps this helped her truthfulness. She wrote for herself so she did not have to adopt a conventional way of writing to meet the editors' satisfaction. As a result, she wrote with freshness and unconventionality. Dickinson's poetry is remarkable for its emotional and intellectual energy. Many modernistic characteristics can be found in it. Dickinson's poems have established her as the most world widely recognized woman and has been regarded as an inspiration to modern writers.

\section{REFERENCES}

[1] ]Bressler, Charles. E. Literary Criticism an Introduction to Theory and Practice. Beijing: Higher Education P\& Pearson Education P, 2004.

[2] Dickinson, Emily. The poems of Emily Dickinson.3 vols. Ed. Thomas Johnson. Cambridge: The Belknap Press of the Harvard UP, 1955.

[3] Li Ling, BaiYanjun "Modernistic characteristics of Emily Dickinson's poems" J.CENT.SOUTHUNIV. (SOCIAL SCIENCE) vol.11 No.1 Feb.2005.

[4] Lowell, Amy. Tendencies in Modern American Poetry. New York: Macmillan Company, 1917.

[5] Martin, Wendy Ed. the Cambridge Companion to Emily Dickinson. Shanghai: Shanghai Foreign Language Education P, 2005.

[6] Pinsky, Robert. The Situation of Poetry .Princeton: Princeton UP, 1981.

[7] Ronald Gottesman. The Norton anthology of American literature.New York: W.W. Norton and Company, 1979. 